\title{
Ecogenesis and primary soil formation on the East European Plain.
} A review

\author{
Evgeny V. Abakumov*, Elena M. Koptseva
}

Saint-Petersburg State University, 16 line 29 Vasilyevskiy Island, 199178, Saint-Petersburg, Russia

\begin{abstract}
AbaKumov, E.V., KoptSeva, E.M., 2022. Ecogenesis and primary soil formation on the East European Plain. A review. Folia Oecologia, 49 (1): 51-60.

Numerous published studies have shown that soil formation, including primary pedogenesis, is closely connected functionally, energetically and operationally with ecogenesis as a key biogenic exploration mechanism of the Earth's surface by living organisms. The ontogenetic stage of soil evolution, especially in the initial phases, is determined by geogenic conditions and the intensity and trends of biogenic-accumulative processes in the developing ecosystem. Primary soils are considered critical in the rapid development of the initial ancient biosphere, supporting multiple environmental possibilities for ecosystems in that stage of their formation. Currently, similar models of correlated soil formation and ecogenesis are actualised when new substrates appear suitable for biogenic-abiogenic interactions, which occur in both natural and anthropogenic landscapes. Biotic factors during primary pedogenesis have accumulative and transformative effects on the edaphic component complex. At this stage, the initial pedon is a key functional stage in the evolution of terrestrial ecosystems (biogeocenosis). When restoration of natural ecosystems occurs during the independent growth of exposed substrates, the natural regeneration mechanisms normally occur. These processes are based on the biogenic development of the substrate through the accumulation and transformation of organic matter.
\end{abstract}

\section{Keywords}

chronology, pedogenesis rate, Russian Federation, soil development, successions

\section{Introduction}

Edaphic (soil) basis plays a key role in the formation and sustainable existence of terrestrial ecosystems (DoKUCHAEV, 1949). Soil formation (pedogenesis) normally starts from biogenic-abiogenic interactions on the surface of solid or unconsolidated bedrock. This stage is considered the initial stage of soil formation, temporally corresponding with biocrust formation (ZAVARZINA and ZAVARZIN, 2012) and the development of lithobiotic ecosystems (EGLI, 2001). The next stage of soil evolution is ontogenesis (ZAKHAROV, 1945), i.e. the development of the soil body vertically until the first sign of genetic soil horizon formation. By the end of this stage, soils enter the zonal soil formation stage (MOKMA, 2001) in benchmark zonal ecosystems. Since the work of Dokuchaev, the taxonomy, diagnostics and pedology of zonal soils have been intensively investigated. However, the details of primary soils development, including processes, rates and bioclimatic invariance, remain underexplored (Frouz, 2013). Thus, the aim of this review was to explain what is known about initial (primary) soil formation in various environments and to analyse data from our group and others on the rates of initial soil formation within four climatic belts of the East European plain.

\footnotetext{
*Corresponding author:

e-mail: e_abakumov@mail.ru; e.abakumov@bio.spbu.ru 


\section{Theory and methodology}

The regional setting was dialled using a long term field survey of pedologists and geobotanists within the zonal (latitude) scale in the following sequence of zones: Arctic tundra, tundra, taiga, forest-steppe, steppe, dry steppe and dry subtropics. Field studies were conducted in 2006-2015 in the East European Plain (Russian Federation). The soil of various ages in comparable lithological and topographical conditions was selected to account for the temporal variability of soil formation in every soil bioclimatic zone. Every zone is represented by at least 5-15 plots, described and sampled in a spatial chronoseries. The soil profile (solum) depths ranged from $1 \mathrm{~cm}$ (in the very initial formation stage) to $90 \mathrm{~cm}$ (in developed soil at the end stage of succession). Essential to the methodology was investigating soil chronoseries in similar geogenic conditions (flat relief, spatial and vertically homogenous parent materials of various compositions and geneses). In this case, we can use different aged soils as stages of chronoseries, i.e. soil developed within the same period. The soil of different ages was described and sampled, and soil data analyses and interpretation have been published (АВAKUMOV et al., 2010). In this study, we discuss the morphological trends of soil development with taking into account data of chemical characteristics. We also incorporate data from numerous published sources to interpret the nature of soil processes. Thus, this study considers the rate of initial soil formation, the role of biological processes in soil formation and temporal models of soil evolution within various soil chronoseries.

\section{Soil naming and terminology}

Soil terminology and the naming of primary soils are now well developed compared to the World Reference Base of Soil resources (2014-2015). In Russian soil taxonomy (2004), "small horizons" refers to undeveloped, fragmentary, very thin soil layers with some features of a normal (developed) horizon. For example, the initial version of Podzol has an "e" horizon, while developed Podzol has the eluvial E horizon. So, the terminology of soil horizons for initial soils is different from standard developed soils. In this context, the horizons designations provided in Figs 1-5 could only partially correlate with WRB and Russian soil taxonomy because they represent specific horizons. Thus we can compare our horizons with WRB in the following pairs: O, Aao, Oe - Follic, G, Gox, Cg - Gleyic, AU - Mollic, Cca - Petrocalcic, BMK - Cambic, BF Spodic, CR - Gelic, Cryic, E - Podzolic. In soil names, it is helpful to use the prefix Entic for soils with some features of zonal soil formation.

\section{Relationships of ecogenesis and pedogenesis}

The formation and evolution of various life forms are linked to the evolution of their habitat (LEvCHENKo and Skorobogatov, 2014). Development and transformation of initial soils into zonal full-profile soils normally occurs in the co-evolution of soils, plants and animals (RAZUMOVSKIY, 1981). There are five main factors that influence the process of soil formation: parent material, topography, climate, organisms and time (MatchaVARIANI, 2019). Independent soil development in the evolutionary process is closely related to the formation of the initial ancient biosphere. Some primary soils remain at the initial stage for hundreds and thousands of years, and other primary soils develop into the mature/climax, quasi-stationary, zonal (full-profile) version. The theory of the soil processes hierarchy was originally based on the analysis of vertical profile differentiation (DoKUCHAEv, 1949). The main processes among these are those of the biogenicaccumulative group (PonOMAREVA and PlotNiKova, 1980; Tolchelnikov, 1985; Smagin, 2010). Since soil formation without biogenic processes is impossible, soils arise only in those compartments of the biosphere covered by terrestrial biota as a source of biogenic elements and energy (ArChegova, 1992; 2009). Our results show substantial differences between natural soil patterns under different rainfall input. With higher rainfall, soil patterns become more heterogeneous due to increased tree throw and water erosion. Agricultural patterns differ substantially from the natural patterns, with higher variation of soil properties over larger distances and larger correlations with terrain position. In the natural system, rainfall is the dominant factor influencing soil variation, while for agricultural soil patterns landform explains most of the variation simulated. The cultivation of soils thus changed the dominant factors and processes influencing soil formation and thereby also increased predictability of soil patterns. Our study highlights the potential of soil-landscape evolution modeling for simulating past and future developments of soil and landscape patterns. Our results confirm that humans have become the dominant soil-forming factor in agricultural landscapes. (KOMAROv, 2009) and the corresponding dynamics of biogenic-accumulative processes (SMAGIN, 2010). Nevertheless, there are "soloids", peculiar soil-like bodies that do not contain biota and humus compounds (GorYachKIN et al., 2019). Both concepts fit well into the theory of "extraordinary soils" (ToLCHELNIKov, 1985).

The doctrine of the evolutionary development of the soil-plant system was originated by CLEMENTs (1916), who analysed the ecogenetic and demutational changes of phytocenoses and soils. Ecogenesis is closely related to pedogenesis as a general biosphere process and a local biogeocenotic phenomenon (RAZUMOVSKIY, 1981; CHERTOV, 1983; RABOTNOV, 1992). Because ecogenesis is one of the stabilising factors of the evolution of terrestrial ecosystems (Severtsov, 1990), it is closely connected with the soil formation process. Moreover, soil formation within the developed ecogenesis is functionally associated with the divergence of ecological niches and the so-called "ecological licenses" in terrestrial ecosystems (LEVCHENKo and Skorobogatov, 2014). Ecogenetic and demutational changes of communities determine and are largely determined by the sub cyclic changes in the edaphic conditions of pedogenesis, which leads to the development of a single edapho-ecosystem process manifested in morphological and parametric dynamics of soil organoprofiles 
(Archegova, 2009; Androkhanov et al., 2004). Thus, primary soil formation is mainly driven by biogenic ecosystem processes occurring at a higher rate than in mature soils. That is why the reclamation practices and technologies should be based on the driving forces of biogenic accumulative and biogenic transformative elementary soil processes. Of course, primary soil formation essentially varies by climatic conditions. For example, the rate of solum development is normally higher in boreal environments than in sub-boreal ones because of the humidity and precipitation/evaporation ratio. Thus, cooler regions of the taiga normally show more intensive soil development in the initial stages than warmer but essentially dryer regions of sub-boreal steppes.

\section{The rates of primary soil formation}

In the context of the study of the successful ecogenesis of terrestrial ecosystems, the question of the rate of initial (initial, primary, regenerative) soil formation (EMMER, 1995; Mokma, 2004; Abakumov et al., 2010; Frouz, 2013; TARGULIAN, 1985) is particularly relevant.

For more than a century, models of rapid ontogenesis of soils have been studied in soil science and factorial ecology. The formation model of the soil profile in ontogenesis has been studied primarily in chronoseries beginning with the "zero-moment" of soil formation and ending with the formation of the zone soil profile. This type of model is interesting for studying linear rates of soil formation, as it allows us to evaluate trends in system development of organogenic and organo-mineral horizons in short and recent time intervals. This type of soil formation is shown in Fig. 1, which provides as an example the chronoseries of different aged south taiga podzols (Leningrad region, NW Russia) (ABAKUMOv et al., 2010).

Numerous data obtained in the study of soils in linear and relatively simple ontogenetic models of soil formation have made it possible to establish characteristic formation times of a specific soil zone profile (AlEXANDrovsKIY, 2002). The interpretation of formation scenarios for overmoist or eroded soil evolution is more complicated. This version of a demutation series is characterised by the incomplete disappearance of soil information, saved in the morphological and chemical features of the previous stages of soil formation (RAZUMOvSKIY, 1999). The most outstanding examples of demutations are post-fire changes of soil and vegetation (FuraEV, 1996; TsIBART and GENADIEV, 2009; RoBICHAUD et al., 2010), post-erosion and afforestation series (NyBERG et al., 2012; RuSANOv, 2012) and erosion often resulting from wildfires or strong anthropogenic impacts.

Normally, all demutation series, except for primary successions on completely exposed substrates, inherit certain features, properties and resources of previous soils, so evolutionary models here are not linear or readily interpreted (TARGULIAN, 2008). Nevertheless, these series are attracting increasing attention from scientists as examples of the constantly repeated evolution of soils in certain ecosystems. In this context, in modern pedology and factorial ecology, several research directions in rapid soil evolution, its analysis and prognosis have developed: studying simple models of pedo-ontogenesis, examining various polygenetic models of soil ontogenesis, conducting the parametric analysis of "efficiency" of soil self-restoration, determining parameters of productivity of ecosystem functioning during their formation and analysing demutation interactions with soils (CLEMENTS, 1916). It is noteworthy that soil development processes are closely related to ecogenesis as part of the edaphotope formation process. In this regard, studying the evolution of edaphotopes in chronoseries in various scenarios is a high priority for modern environmental soil science.

The vast majority of modern soils were formed over thousands of years. Most of the East European plain soils are of the Holocene age (ALEKSANDROvSKIY, 2002). However, many landscapes are characterised by younger soil formations, particularly predominant in NW Russia and other recent postglacial territories. KovDA (1973) pointed out that primary soil formation could be an informative model for investigating soil evolution. This process was key in plant organisms developing the planet's surface $\left(\mathrm{Z}_{\mathrm{A}}\right.$ VARZINA and ZAVARZIN, 2013) and remains the main one in soil and vegetation cover regeneration in disturbed areas (MaKhonina, 2004). According to Kovda (1973), the concept of primary soil formation is of central importance in developing the doctrine of holistic soil evolution. If there were primary soils at the initial stages of biosphere devel-
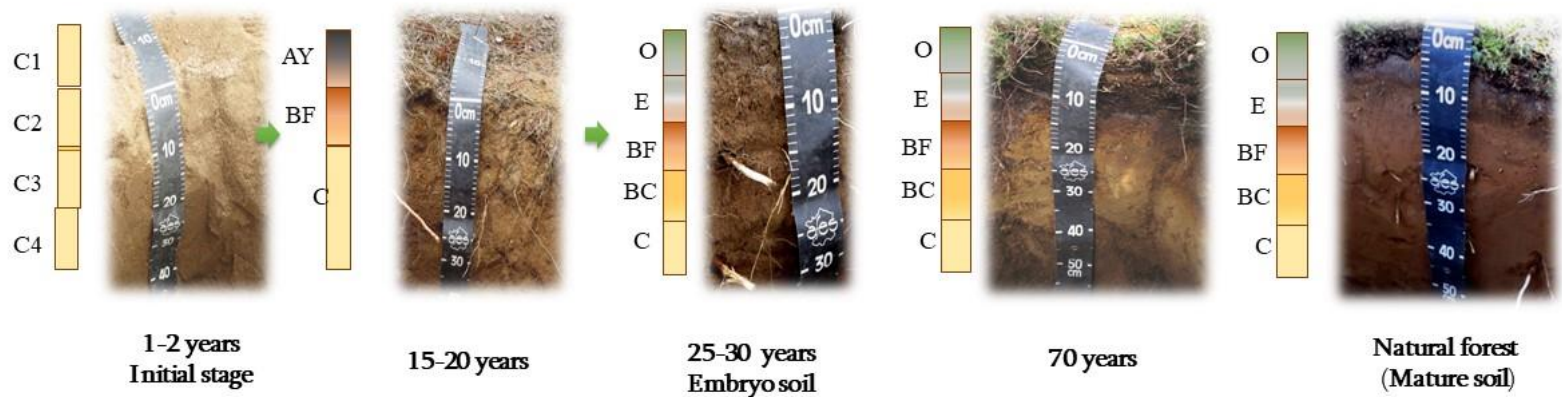

Fig. 1. Soil development in chronosequence on fluvioglacial sands of temperate zone (boreal, taiga belt). Designations: $\mathrm{C} 1-\mathrm{C} 4$ - various layers of parent materials, AY - gray-humus sod horizons, BF - horizon of iron illuviation, $\mathrm{E}$ - podzolic layer, $\mathrm{BC}$ - transitional layer. 
opment (ebmriobiosphere formation stage) (LAVCHENKo and Skorobogatov, 2014), initial soils should be referred to as a specific stage of any soil evolution. ZAKHAROV (1945) identified three periods in soil development: 1. ontogeny of the soil - a development from the rock, leading to the formation of a typical organisation, 2. soil evolution - soil change without changing soil formation factors and 3. soil metamorphism - further alteration of the soil profile. This interpretation is similar to the analysis of the organisational change of associations, according to RAZUMOVSKY (1981). RoZANOV (2004) identified three cycles in soil life, small, large and geological. This understanding of soil evolution is more related to landscape geochemistry. Moreover, the small cycle is most closely related to primary soil formation, which well corresponds to the biogenicabiogenic interpretation of the primary soil formation.

TAGRULYAN (1985) divided the period of independent soil development into several stages: 1) zero-moment of rock exposure on the day surface and proto-soil stage of predominantly abiogenic transformation, 2) pre-soil in which biota are present and intensive biogenic soil alteration occurs without evident development of soil horizons, 3) ephemeral presence of primary and young soils developing under the primary successions of biota, differentiation of soil horizons, the beginning of deep soil profile growth, 4) developing soil in which the advanced development of biogenic components in the ecosystem drives the development of soil, and there is further deep soil growth and development of the extinction horizons, 5) optional stages of quasi-climax soil metamorphoses to the biota feedback principle, 6) pre-climax stage of asymptotic deceleration of soil self-development and 7) terminal stage of climax (mature) soil.

This scheme is the most complete, and it contains the idea that the development of vegetation community is ahead of the development of soil (RODE, 1984). Interpretation of the leading role of biota in soil development is not always supported by geobotanists (RAZUMOVSKIY, 1999). Thus, the simultaneous development of soil and phytocenosis often represents an ecogenetic succession. This succession already contains a conjugate (rather than priority) change in the phytocenotic and soil components of biogeocenoses, while, we suggest, the soil is not delayed relative to the development of the community but, on the contrary, reacts very quickly to these changes. RAZUMOVSKY (1999) indicates that the stable or climactic state of vegetation community is most often unrealistic since certain areas of space are often disturbed on the current surface of the Earth.

In the initial stages, soil formation is associated with the processes of weathering, destruction of massive crystalline rocks, limestones, dolomites and other rock types. Lithophilic organisms, including bacteria, micromycetes, and vascular plants, play a huge role in this process. These organisms are often extremely adaptable to environmental conditions, can consume negligible amounts of nitrogen and organic compounds and withstand dryness and sharp temperature fluctuations. KovdA (1973) was the first to mention the development of a self-different "embryonic" soil formation process as a function of the vital activity of lithophilic microorganisms. Lichens play an essential role in developing the rock environment, releasing organic matter to heterotrophic organisms. During succession, mosses appear on a prepared, weathered substrate and contribute to the further destruction of the skeleton and smallscale formations. Normally, on hyperskeltic materials, lithobionts act as "retainers" of silt particles transported by the wind. Thus, primary fine earth accumulates around the microenvironments of mosses and lichens (KAPELKINA et al., 2014); a similar pattern is often observed on aeolian sediments (KoptSEva, 2012).

Thus, the concept of lithobiotic successional (soilontogenetic) series exists in geobotany and soil science. Soil formation on fine-textured substrates can be considered a lithobiotic process in which the mineral portion of the soil is less resilient to the effects of organic degradation products than the massive crystallic bedrocks of classical lithogenic soils. Support for this idea can be found in the original and still modern conception of "humus in connection with the unconventional understanding of the soil" (ARCHEGOVA, 2007). The idea that any soil formation is lithobiotic or lithobiological, as in KosTYCHEV (1937), indicates that the main material factors or forces of soil formation are biota and rocks. Another interpretation of this idea is that biota can be considered "moderators" of the biolithogenic (biogenic-abiogenic, according to V.V. Dokuchaev) process.

Considering our own and other published data mentioned above allowed us to conceptualise the types of initial soils that can form on the different temporal stages of ecogenetic series in polar, boreal, sub-boreal and subtropical environments. A graphical view of the results is shown in Figs $2-5$. These pictures depict only soil ontogenesis, not further stages of soil evolution. The soil profiles and horizons vary greatly independent of the bioclimatic belt, appearing to be more dependent on the type of substratum initially exposed. In general, in polar parts of the European Arctic, there are two types of parent materials: with or without a permafrost table in the top $1 \mathrm{~m}$ of soil. Permafrost (Fig. 2) affects soil development, assisted by the stagnification and gleyification of the suprapermafrost layer ( $\mathrm{Cg}$ ) and the formation of organic layers and the moor/ moder humus horizon (Ah). Furthermore, the cryogenic mass exchange results in the formation of the primary cryogenic horizon (CR) and consequent transportation of organic matter $([\mathrm{H}]$ - buried organic material), which can be expressed not only in the evident layer but in the form of spots. When the permafrost layer border is deeper, soils profiles development is less influenced by cryogenic processes. This type of soil formation is similar to podzolisation, but the rate of weathering and eluvial leaching of substances is less than in boreal environments. Thus, in this case, we have so-called "hidden" Podzol, Entic Podzol or Podbur (TARgulian, 1985).

The highest soil profile differentiation rates are typically observed in taiga (boreal) ecosystems (Fig. 3). These rates result from the absence of permafrost and favourable conditions for intense vegetation in humid conditions (Ponomareva and Plotnikova, 1980). The main soil formation trend, in this case, is weathering and eluviation of 


\section{Arctic}

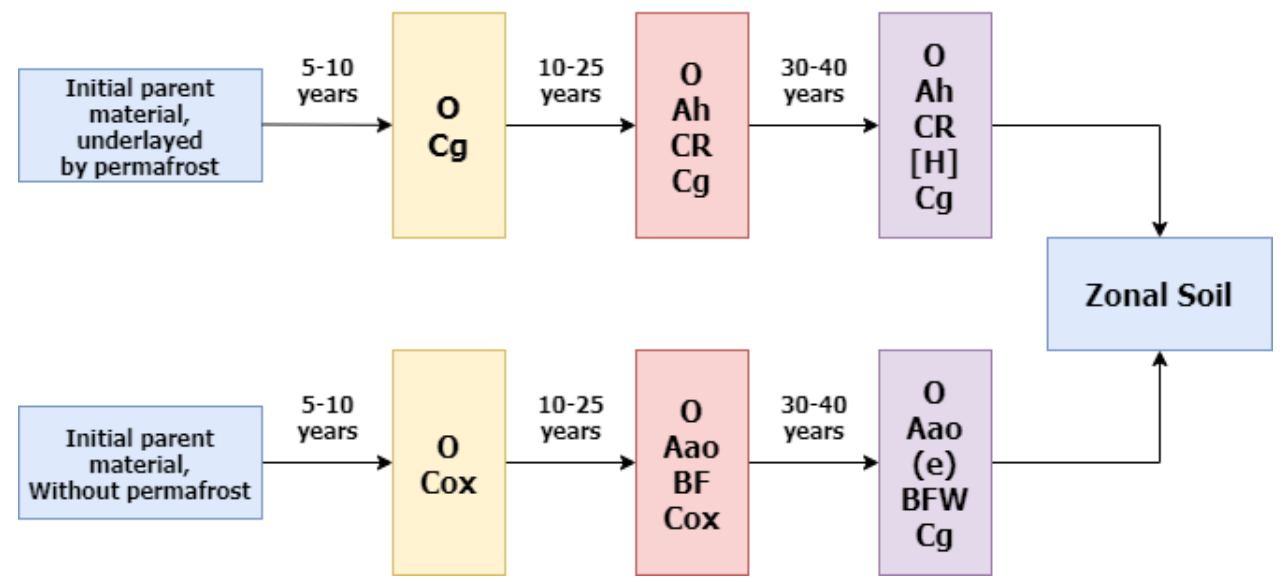

Fig. 2. Primary soil development in the Arctic belt (mining derived parent materials). Designations: $\mathrm{O}$ - organic remnants, $\mathrm{Cg}$ - gleifiyed parent material, $\mathrm{Ah}$ - humus horizon with features of humus migration, $\mathrm{CR}$ - horizon of intensive cryogenic mass exchange, Aao - moor humus, $\mathrm{Cg}$ - gleyic layer, BF - horizon of iron illuviation, BFW - initial cambic features combined with iron illuviation, (e) - initiation of eluvial horizon formation, $[\mathrm{H}]$ - buried raw organic material, Cox - parent material with features of reductimorphic properties, Aao - raw humus horizon.

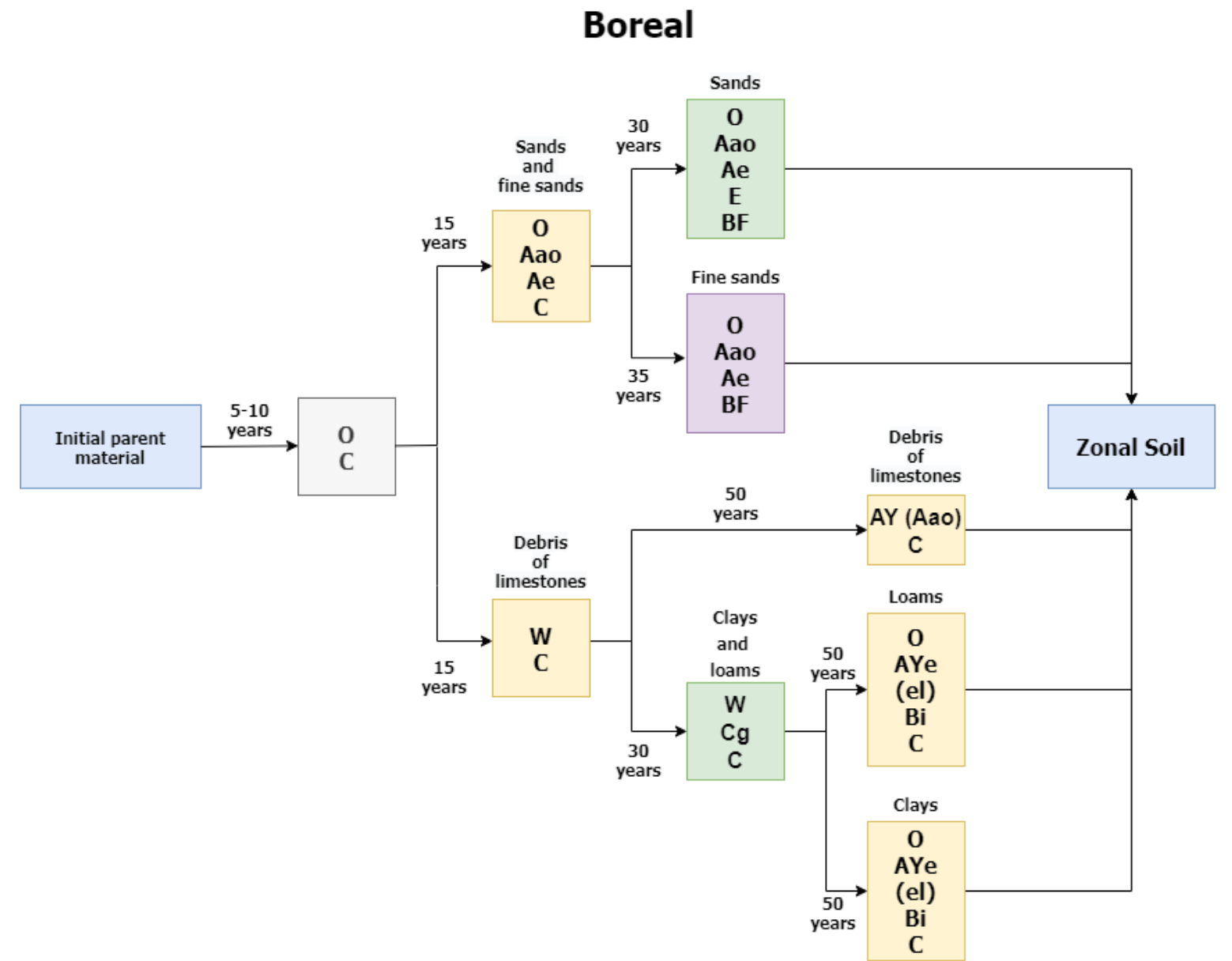

Fig. 3. Primary soil development in the Boreal belt. Designations (if differ from presented in Fig. 2): W - weak developed accumulation of humus, $\mathrm{Cg}$ - gleyified horizon, AY - gray humus sod horizon, AYe - gray humus horizon with few features of podsolization, Ae - transitional humus-eluvial horizon, E - podzolic horizons (el) - horizon with initial features of lessivage, $\mathrm{Bi}$ - horizon with initial features of illuviation of clay fraction, $\mathrm{O}$ - horizon of accumulation of organic remnants, $\mathrm{C}-$ parent material, Aao - raw humus horizon. Mining derived parent materials. 
the topsoil mineral compound and gleyification in the presence of clayey textured parent materials. It should be emphasised that the eluviation-podzolisation rate is highest on sandy and fine sandy textured soils, lower in loam and clayey textured ones and not expressed in calcaric soils.

In sub-boreal environments (Fig. 4), the key pedoenvironmental characteristics are a lack of precipitation and negative hydrological conditions. As a result, the movement of substances from topsoil to deeper horizons is sporadic and does not result in essential differentiation of the mineral portion of the rock. Thus the initial stage of soil ontogenesis is represented by the development of mull-type humus enriched topsoil, sublayered by a weakly altered horizon. The degree of soil profile differentiation is independent of the degree of parent material consolidation. Soil evolution of consolidated rock is implemented on lithosol types or calcaric if the bedrock was carbonate. In unconsolidated sediments of the terra rossa type, normally carbonate-containing, the most probable path of soil formation is mull-humus enrichment and in situ weathering of mineral solum with a secondary accumulation of dehydrated colloidals, which results in soil cover browning.

The initial subtropical soils vary depending on the degree of stone content and consolidation rates of the parent materials (Fig. 5). Thus, the rate of initial soil formation is essentially higher on lesser consolidated rocks than on denser ones. Remarkably, the rate of pedogenesis reflects the rate of parent material weathering, which is quite dif- ferent in humid and dry subtropic environments.

In the context of the abovementioned information, we conclude that the biolithogenic variability of soils in time, space, and the vertical gravitational axis scale provides the basis for primary soil formation. The primary soil formation under vascular plants is most intense during the first 10-20 years (SHRESTHA and LAL, 2010), consistent with generalising data of Alexandrovsky (2002). The intensive temporal decline of the rates of the organo-accumulative process is characteristic even for soils formed on rocks, initially containing organic matter (GANJEGUNTE et al., 2009), the levels of soil respiration also sharply decrease with age (TANG, 2009); thus, there is a rapid metabolic start of pedogenesis and a subsequent slower process of profile differentiation. It is necessary to emphasise that invertebrate animals (WANNER and DUNGER, 2002) play a huge role in forming primary soils, but this topic is still under investigation. In general, the synthetic parameterisation of biological factors of soil development in lithobiotic systems is currently unexplored.

\section{Biogenic processes and soil formation}

The main processes involved in the formation of young soils are biogenic accumulation and the transformation of organic matter (MeHDIYEv, 2021). These processes are most clearly manifested in the early stages of soil develop-

\section{Subboreal}

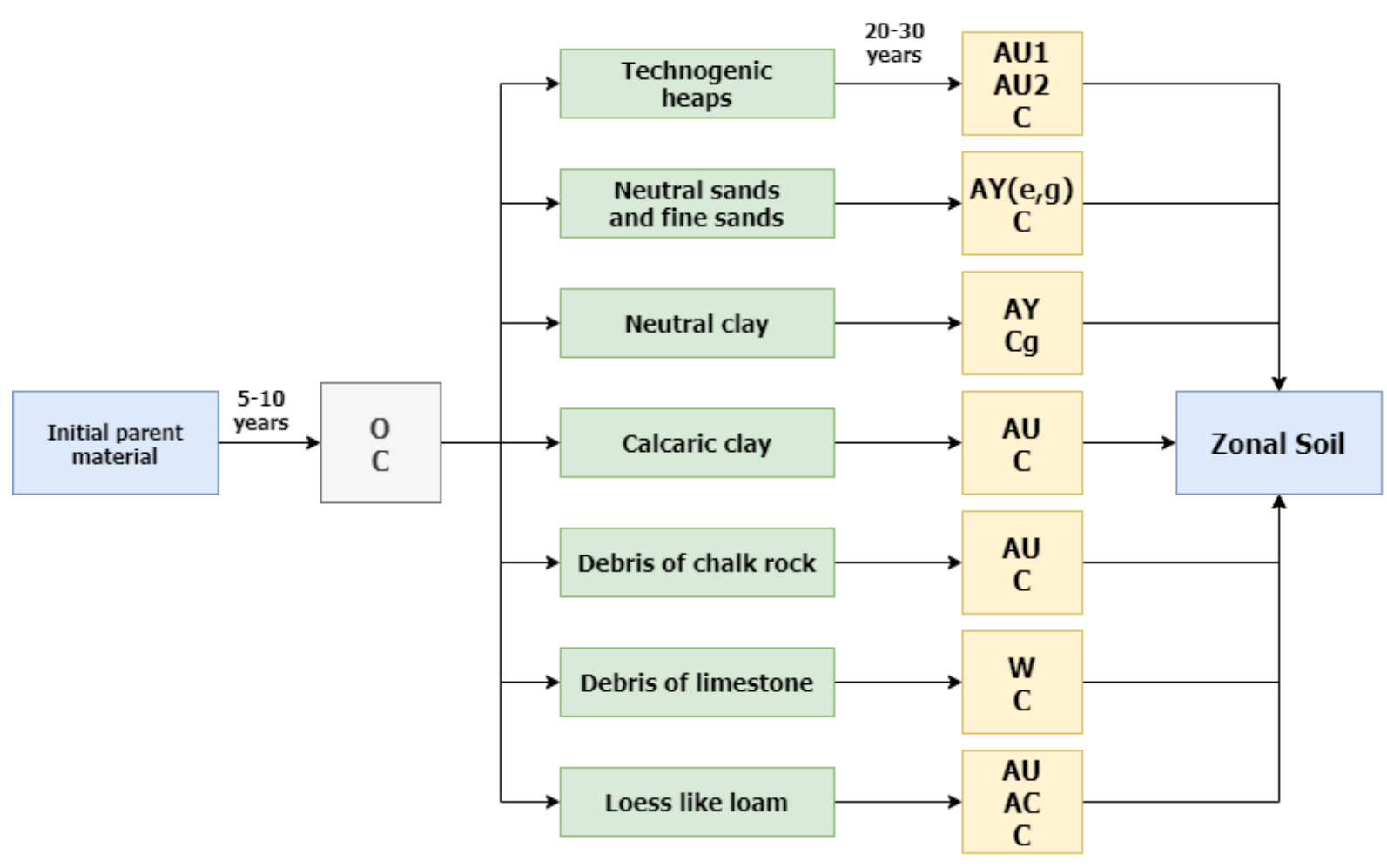

Fig. 4. Primary soil development in the Subboreal belt. Designations (if differ from presented in Fig. 2 and 3): W AU - dark humus horizon (AU1 and AU2 - features of constituent differentiation), AC - transitional horizon, AY(eg) - gray humus horizon with few signs of lessivage and gleyification. Mining derived parent materials. 


\section{Subtropic}

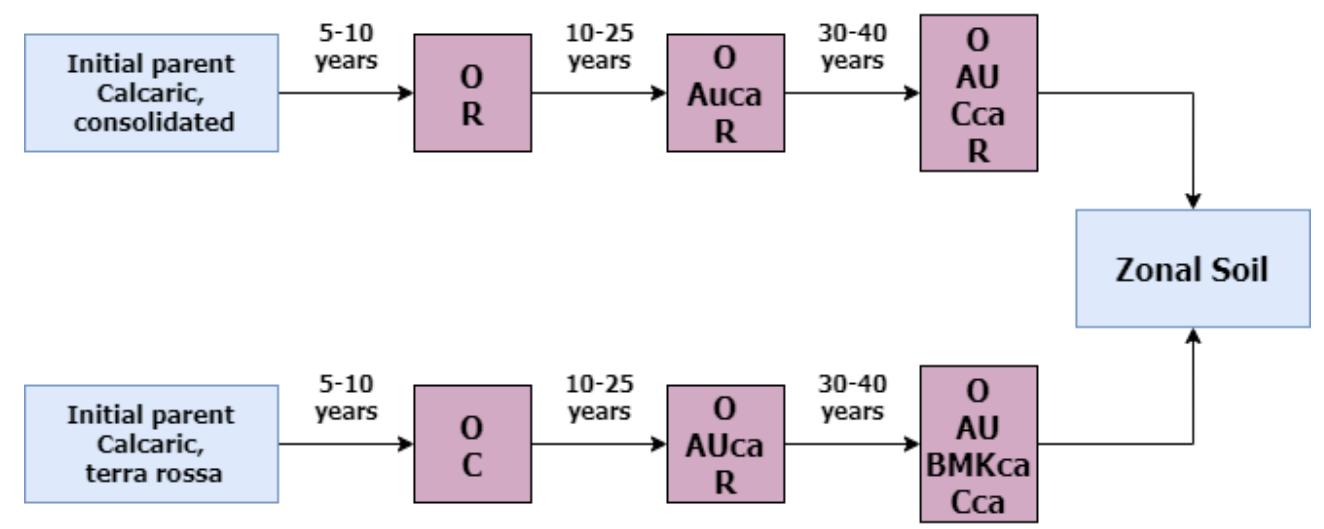

Fig. 5. Primary soil development in the Subtropic belt. Designations (if differ from presented in Fig. 2): AU - dark humus horizon, $\mathrm{R}$ - hyperskeletic parent material, BMKca - Calcaric layer with cambic features, $\mathrm{ca}$ - the presence of lithogenic $\mathrm{Ca}$, AUca - dark humus horizon with secondary accumulation of calcium, Auca - initial stage of formation of AUca, Cca - friable parent material with presence of lithogenic carbonates.

ment, and their characteristics are proposed by researchers as indicators of soil formation intensity. It is known that the functional unit driving interaction of soil and vegetation cover within the ecosystem is an organic substance or soil humus (Ponomareva and Plotnikova, 1980). Ewald (1972) described the soil formation model of soil development, in which the biological accumulation of substances is the first pedogenesis process, followed by leaching out of substances and alteration by weathering of the mineral portion (components of eluvial-illuvial differentiation and in situ soil weathering). Vegetation has a significant effect on all of the water erosion processes. Usually, primary succession is accompanied by an increase in soil resistance to concentrated erosion because plant metabolites contribute to the formation of water-resistant aggregates and thereby increase the stability and infiltration of soils (FAO, 2019).

In fact, the classification scheme of initial soil formation processes in post-technogenic ecosystems, proposed by ANDROKHANOV et al. (2004), is similar to this system that identified three groups of processes. The first group includes those processes directly related to the transformation of organic matter over a short period. The values of their characterising indicators change most rapidly, and the processes constitute the genetic and ecological nature of pedogenesis. The second group includes processes poorly controlled by organic matter transformations, and their key changes occur more slowly. These include changes in the cation exchange capacity and lessivage. The final group of processes is very weakly associated with the transformation conversion and accumulation of organic matter. These processes have long characteristic times and include changes in the mineralogical and bulk chemical composition of soils. Thus, the functional classification of soil processes is based on the degree of manifestation of biogenic processes and their presence or absence (ARCHEGOVA, 2007). Biotic factors in the formation of young soils in the initial post-formation years have accumulative (accumulation of carbon, nitrogen and other biogenic elements) and transformational (structure formation, weathering and turbocharging processes) roles (REYNTAM, 2001).

The relationship between plants and soil should be considered as a specific type of ecosystem interaction (Popov, 2012). The loose substrate for example sand is mobile and along with other environmental factors serves a driver for the redistribution and formation of the soil seed bank of anemochore plants during primary succession in quarries (Sumina and KoptSEva, 2019). In general, the granulometric (particle size) composition largely determines the biodiversity of colonizing plants (EGOROV et al., 2019).

Recent research at the intersection of geobotany and soil microbiology revealed the essential role of the mycorrhiza factor of roots on the rate of initial ecogenesis and primary soil formation (GorbunOva and Sumina, 2021). It has been shown that arbuscular mycorrhizae are a specific component of the pedosphere and act as an intermediary between the soil and the plant. Thus, in the soil-plant system, mycorrhizae affect the physiology and vitality of individual plants and significantly impact the biogeochemical functioning of the entire ecosystem.

\section{Temporal models of initial soil evolution}

Time is the most important factor in soil formation. Space and time allow for the manifestation of other material and energy factors (GENNADIEV, 1990) that are necessary for the manifestation of soil evolution (ZAKHAROV, 1945). It should be noted that soil regeneration after destructive effects, in most cases, begins at a zero point, and soil evolution can be most clearly and accurately parameterised within the initial stage of soil formation. The results of studies of this stage provide background data supporting 
the theoretical basis for the restoration of soil resources in the regeneration process of post-technogenic ecosystems. Soils within a chronoseries, including ecogenetic series, are very effective tools of retrospective assessment of soil development (KHITROV, 2008).

The main parameter by which the developing soils of initial ecosystems of recently exposed lithogenic surfaces can be referred to as models is the known soil formation start time ("zero-age") under certain bioclimatic and lithological-geomorphological (geogenic) conditions. We can designate this object as a model since we are discussing the semblance of the phenomenon (soil formation process) and not the process itself (GENNADIEv, 1990). Imitation of soil formation is carried out when interpreting and generalising data obtained from the study of soils of different established ages formed under similar conditions on the same bedrock materials. Such sequences of soil development in time are called chronosequences or chronoseries. The basis of the discussed type of models is the property of soil ergodicity, i.e. the ability of the soil body to have spatial analogues corresponding to the chronological stages of its development (GenNADIEv, 1990). Within the genetic model framework of soil formation (IvANOV and AleKsANDrovskiy, 1987; SoKolov, 1997), primary soils are the most easily amenable for theoretic interpretation of separate soil processes and holistic formation of soil profiles. Even when studying single soil bodies of a certain age, we can talk about a very promising simulation of soil formation, despite the inability to take advantage of the property of soil ergodicity. The essence of the simulation is to study the results of the manifestation of elementary soil formation processes that occur over relatively long, specific periods (formation of organogenic horizons, primary differentiation of the soil profile, formation of organomineral compounds and soil absorbing complexes). Some of these processes can be investigated in a laboratory experiment, the advantages of which include the controllability of conditions and the elimination of substrate heterogeneity (RoDE, 1984). The main shortcomings of laboratory experiments are the difficulties encountered in studying processes that occur over more than several years. According to the definition of TARGULIAN (1985), the active manifestation of elementary soil processes is expressed in solid-phase products of soil functioning. Small annual increments in the solid phase soil features cannot always be captured by traditional analytical methods due to the existing concentration of the feature in the soil, especially true for mature soils. In studying initial soil formation, we consider a relatively short duration of pedogenesis and low values of changes in the mineral substrate of the rock, which allows us to fix the course of elementary processes of soil formation.

It should be noted that the model under discussion has some limitations. For example, the researcher cannot always consider the conditions of soil formation in anthropogenic ecosystems in interpreting data. This limitation prompted TARGULYAN et al. (1989) to define soil chronoseries as semi-experiments. In addition, newly exposed substrates are characterised by high lithogenic heterogeneity and have long been under conditions of natural or anthropogenic surface modelling (Trofimov, 1979; Gadzhiev et al., 2001). Analysis of soil-chronological data on recent substrates by MAKHONINA (2004) revealed their extreme diversity, regional features and significant inconsistency, indicating significant invariance of initial pedogenesis. Furthermore, the results of studies by different authors are rarely comparable because soil objects are studied under various substrate-phytocenotic and bioclimatic conditions. We propose that the creation of databases of pedogenesis results over specific periods using multiple natural zones, vegetation types and lithological matrixes will be very promising not only for the accumulation of raw data to develop reclamation technologies but also for solving the fundamental problem - the disclosure of the mechanisms of soil evolution during ontogenesis. The soil chronological data discussed here are consistent with the data of ALEKSANDRovsky (2002), who found that the appearance of diagnostic horizons for soils on sandy and loamy rocks in the normal model of pedogenesis in the taiga zone occurs at the time stages of development of 50-100 and 100-500 years, respectively. The same work by AlexANDrovsky (2002) supports that different soil ontogenesis rates formed in various natural zones. Thus, pedogenesis and ecogenesis are connected in functions, processes, energetics, and chronologies.

\section{Conclusion}

Analysed data showed that primary soils could be considered specific soil communities, representing a chronological compartment of the pedosphere. This community of soils changes in space: some primary soils become mature (developed), others are destroyed and replaced, and bedrocks exposed in their place become substrates for primary soil formation. Thus, primary soil formation is a cyclic process in temporal and spatial dimensions. If the age of formation of the primary initial soil is 5-20 years, which is approximately the same for all soil zones, it should be concluded that the primary soil was an edaphic component of the ancient biosphere and a key part of the current biosphere in various compartments on the Earth. The soil ontogenesis time is the period necessary for the formation of a primary (primitive) ecosystem. During this period, the maximum conjugation of initial ecogenesis and pedogenesis is normally observed. The duration of other stages of soil formation varies greatly depending on the type of soil-climatic zone. In the later stages of soil formation, the dynamics of the temporal evolution of the profile morphotype occur more slowly. Thus, humus formation and related biogenic-accumulative processes, the key mechanism for adapting vegetation to the conditions of terrestrial existence, are the necessary basis for interaction in the soil system with the plant community during ecosystem regeneration. When restoring natural ecosystems in the independent growth of exposed substrates, the mechanisms of natural regeneration processes occur over thousands of years, based on the biogenic development of the substrate through the accumulation and transformation of organic matter. 


\section{Acknowledgements}

This work was partially supported by Russian Science Foundation, project No 17-16-01030.

\section{References}

Abakumov, E., Trubetskoj, O., Demin, D., Celi, L., Cerli, C., Trubetskaya, O., 2010. Humic acid characteristics in podzol soil chronosequence. Chemistry and Ecology, 26 (S2): 59-66. https://doi.org/10.1080/02757540.2010.497 $758 \mathrm{t}$

Aleksandrovskiy, A.L., 2002. Razvitiye pochv Vostochnoy Yevropy $v$ golotsene. Avtoreferat dissertacii na soiskanie uchenoj stepeni doktora geograficheskikh nauk [The development of Eastern European soils in the Holocene. Dr. Sci. Geogr. thesis abstract]. Moscow: Institute of Georgaphy. $48 \mathrm{p}$.

Androkhanov, V., Kulyapina, E., Kurachev, V., 2004. Soils of technogenic landscapes: genesis and evolution. Novosibirsk: Publishing house of the SB RAS. $149 \mathrm{p}$.

Archegova, I., 2007. Thermal regime of tundra soils under reclamation and restoration of natural vegetation. Eurasian Soil Science, 40 (8): 854-859. https://doi. org/10.1134/S1064229307080078

ArChegova, I.B., 1992. About humus in connection with an unconventional understanding of the soil. Pochvovedenie, 1: 58-64.

ArChegova, I.B., 2009. Soil formation during the regenerative succession of forest ecosystems in the North. Sibirskiu Ekologicheskiu Zhurnal, 1: 91-98.

Chertov, O.G., 1983. Mathematical model of the ecosystem of a single plant. Zhurnal Obshchě Biologii, 44: 406414.

Clements, F.E., 1916. Plant succession: An analysis of the development of vegetation. Carnegie Institution of Washington Publication, No. 242. Washington: Carnegie Institution of Washington. 512 p. https://doi.org/10.5962/bhl. title. 56234

DoKuCHAEV, V.V., 1949. Izbrannyye trudy [Selected essays]. Moskow: Selkhozgiz. 647 p.

Egli, M., Fitze, P., Mirabella, A., 2001. Weathering and evolution of soils formed on granitic, glacial deposits: Results from chronosequences of Swiss alpine environments. Catena, 45 (1): 19-47. https://doi.org/10.1016/ S0341-8162(01)00138-2

Egorov, A. A., Koptseva, E. M., Sumina, O. I., Fatianova, E. V., Kirillov, P. S., Ivanov, S. A., Trofimuk, L. P., 2019. Long-term biodiversity monitoring of the spontaneous successions for the assessment of the artificial restoration progress on the quarries in Russian Arctic. Earth and Environmental Science, 263: 1-8. https://doi. org/10.1088/1755-1315/263/1/012002

EMmer, I. M., 1995. Humus form and soil development during a primary succession of monoculture Pinus sylvestris forests on poor sandy substrates. $\mathrm{PhD}$ thesis. Amsterdam: University of Amsterdam. $135 \mathrm{p}$.

EwaLD, E.O., 1972. O vzaimootnoshenii issledovaniĭ v oblasti genezisa i ekologii pochv (na primere izucheniya organicheskogo veshchestva [About relationship in investigation in field of genesis and ecology of soils (on example of soil organic matter)]. Soviet Soil Science, 2: 22-28.

FAO, 2019. Soil erosion: the greatest challenge to sustainable soil management. Rome. $100 \mathrm{p}$.
Frouz, J. (eds), 2013. Soil biota and ecosystem development in post mining sites. Boca Raton: CRC Press. 316 p. https://doi.org/10.1201/b15502

FURYEV, V., 1996. Rol'pozharov v protsesse lesoobrazovaniya [The role of fires in the process of forest formation]. Novosibirsk: Nauka. 248 p.

Gadzhiev, I.M., Kurachev, V.M., Androkhanov, V.A., 2001. Strategiya $i$ perspektivy resheniya problem rekul'tivatsii narushennykh zemel [Strategy and prospects for solving the problems of disturbed land restoration]. Novosibirsk: TsERIS. 37 p.

Ganjegunte, G., Wick, A., Stahl, P., Vance, G., 2009. Accumulation and composition of total organic carbon in reclaimed coal mine lands. Land Degradation \& Development, 20 (2): 156-175. https://doi.org/10.1002/ldr.889

Gennadiev, A.N., 1990. Pochvy i vremya: modeli razvitiya [Soils and time: formation models]. Moscow: Izd-vo Moskovskogo universiteta. $232 \mathrm{p}$.

Gorbunova, A.O., Sumina, O.I., 2021. Dinamika mikorizoobrazovaniya $\mathrm{u}$ nekotorykh vidov rasteniy $\mathrm{v}$ khode vosstanovitel'noy suktsessii na peschanykh kar'yerakh (Leningradskaya oblast') [Dynamics of mycorrhizal formation in some plant species during recovery succession in sand quarries (Leningrad region)]. Botanicheskiü Zhurnal, 1 (106): 22-42.

Goryachion, S.V., Mergelov, N.S., Targulian, V.O., 2019. Extreme pedology: elements of theory and methodological approaches. Eurasian Soil Science, 52 (1): 1-13. https://doi.org/10.1134/S1064229319010046

Ivanov, I.V.A., AleXANDrovsKIY A.L., 1987. Metody izucheniya evolyutsii pochv [Methods for studying the evolution of soils]. Pochvovedenie, 1: 112-119.

Kapelkina, L., Sumina, O., Lavrinenko, I., LaVrineneko, O., Tiknmenev, E., Mironova, S., 2014. Samozarastaniye narushennykh zemel' Severa [Natural revegetation on disturbed lands of the North]. St. Petersburg: VVM Press. $204 \mathrm{p}$.

Khitrov, N., 2008. An approach for a retrospective assessment of soil changes. Eurasian Soil Science, 41 (8): 793 804. https://doi.org/10.1134/S1064229308080012

Komarov, A.S., 2009. Models of plant succession and soil dynamics at climate changes. Computer Research and Modeling, 1 (4): 405-413. https://doi.org/10.20537/20767633-2009-1-4-405-413

Kostychev P.A., 1937. Pochvy chernozomnoy oblasti Rossii: ikh proiskhozhdeniye, sostav $i$ svoystva [Soils of the chernozem region of Russia: their origin, composition and properties]. Moskow: Selkhozgiz. $240 \mathrm{p}$.

KoptSEva, E.M., 2012. Vegetation cover of sand dunes at the mouth of the Voronya River (Murmansk coast of the Barents Sea). Izvestiya Samarskogo Nauchnogo Tsentra RAN, 14 (1(5)): 1276-1280.

Kovda, V.A., 1973. Osnovy ucheniya o pochvakh. Obshchaya teoriya pochvoobrazovatel'nogo protsessa [Fundamentals of the doctrine of soils. General theory of the soil-forming process]. Moskva: Nauka. $447 \mathrm{p}$.

Levchenko, V. F., Skorobogatov, Y.I., 2014. Succession changes and ecosystem evolution (some questions of evolutionary ecology). Russkiu Ornitologicheskiu Zhurnal, 1068: 3533-3550.

MaKhONINA, G. I., 2004. Nachal'nyye protsessy pochvoobrazovaniya $v$ tekhnogennykh ekosistemakh Urala. Avtoreferat dissertacii na soiskanie uchenoj stepeni doktora biologicheskikh nauk [Initial processes of soil formation in technogenic ecosystems of the Urals. Dr. Sci. Biol. thesis abstract]. Tomsk: Ural State University, Ekaterinburg. 38 p. 
Matchavariani, L., 2019. soil-forming factors. The Soils of Georgia. Springer: Berlin/Heidelberg, Germany. https:// doi.org/10.1007/978-3-030-18509-1_3

Mehdiyev, H.G., 2021. Mineralogical and microbiological diagnostics of primary soil formation in the conditions of gray-earth soils of the semidesert zone of the middle part of the Nakhichevan Autonomous Republic. Problemy Nauki, 5(64): 29--37.

Mokma, D.L., Yli-Halla, M., Lindevist, K., 2004. Podzol formation in sandy soils of Finland. Geoderma, 120 (3-4): 259-272. https://doi.org/10.1016/j.geoderma.2003.09.008

Nyberg, G., Bargués Tobella, A., Kinyangi, J., Ilstedt, U., 2012. Soil property changes over a 120 -yr chronosequence from forest to agriculture in western Kenya. $\mathrm{Hy}$ drology and Earth System Sciences, 16 (7): 2085-2094. https://doi.org/10.5194/hess-16-2085-2012

Ponomareva, V., Plotnikova, T., 1980. Gumus i pochvoobrazovaniye [Humus and soil formation]. Leningrad: Nauka. 222 p.

Popov, A.I., 2012. The soil - plant trophosystem is the basis for the functioning of the ecosystem. Ekosistemy, ikh $O p$ timizatsiya i Okhrana, 7: 251-260.

Rabotnov, T., 1978. Fitotsenologiya [Phytocoenology] Moskva: Izd-vo MGU. 384 p.

RAZUMOVsKIY, S. M., 1981. Zakonomernosti dinamiki biotsenozov [Patterns of the dynamics of biocenoses]. Moskow: Nauka. 231 p.

RazUmovskiY, S.M., 1999. Izbrannyye trudy [Selected works]. Moscow: KMK. 560 p.

Reyntam, L.Y., 2001. Humus state in primary soils under the forest on the quarry dumps of the shale industry. Pochvovedenie, 10: 1207-1216.

Robichaud, P.R., Ashmun, L.E., Sims, B.D., 2010. Post-fire treatment effectiveness for hillslope stabilization. General Technical Report RMRS-GTR-240. Fort Collins, CO: U.S. Department of Agriculture, Forest Service, Rocky Mountain Research Station. 62 p. https://doi.org/10.2737/ RMRS-GTR-240

Rode, A.A., 1984. Genezis pochv i sovremennyye protsessy pochvoobrazovaniya [Soil genesis and modern factors of soil formation]. Moskva: Nauka. 254 p.

Rozanov B.G., 2004. Morfologiya pochv [Soil morphology] Moscow: Akademicheskiu Proyekt. 432 p.

Rusanov, A.M., 2012. The current stage of the evolution of agro-landscapes of steppe and forest-steppe zones (on the example of the Orenburg region). Vestnik $O G U, 6$ : $128-132$.

SEVERTSOV, A.C., 1990. Intraspecific diversity as a cause of evolutionary stability. Zhurnal Obshcheı Biologii, 51 (5): 579-589.

Shishov, L.L., Tonkonogov, V.D., Lebedeva, I.I., GeraSIMOva, M.I., 2004. Klassifikatsiya i diagnostika pochv Rossii [Classification and diagnostics of soils in Russia]. Smolensk: Oykumena. 341 p.

Shrestha, R.K., LaL, R., 2010. Carbon and nitrogen pools in reclaimed land under forest and pasture ecosystems in Ohio, USA. Geoderma, 157 (3-4): 196-205. https://doi. org/10.1016/j.geoderma.2010.04.013
Smagin, A.V., 2010. Biogeofizicheskiye mekhanizmy samoorganizatsii dolinnykh lesnykh ekosistem na pochvakh legkogo granulometricheskogo sostava [Biogeophysical mechanisms of self-organization of valley forest ecosystems on soils of light granulometric composition]. Ekologicheskiu Vestnik Severnogo Kavkaza, 6 (4): 17-29.

Sokolov, I.A., 1997. Pochvoobrazovaniye i ekzogenez [Soil formation and exogenesis]. Moscow: Pochv. in-t im. V.V. Dokuchayeva. 239 p.

Sumina, O. I., Koptseva, E. M., 2019. Seed distribution drivers at an early stage of vegetation development in a sand quarry. Tomsk State University. Journal of Biology, 46: 48-63. https://doi.org/10.17223/19988591/46/3

Tang, J., Bolstad, P.V., Martin, J. G., 2009. Soil carbon fluxes and stocks in a Great Lakes forest chronosequence. Global Change Biology, 15 (1): 145-155. https://doi. org/10.1111/j.1365-2486.2008.01741.x

Targulian, V., Goryachinin, S. (eds), 2008. Pamyat' pochv: Pochva kak pamyat' biosferno-geosferno-antroposfernykh vzaimoderstvǐ [Soil memory: soil as a memory of biosphere-geosphere-anthroposphere interaction]. Moscow: Inst. Geogr., Russian Acad. Sci. 692 p.

TARGULIAN, V.O., 1985. Planetarnyye ekzogennyye protsessy i pochvoobrazovaniye [Planetary exogenous processes and soil formation]. Izvestiya Akademii Nauk SSSR. Seriya Biologicheskaya, 6: 51-59.

TOLCHELniKov, Y.S., 1985. O sushchnosti ponyatiya "Pochva" [About the essence of the concept of "Soil"]. Vestnik Moskovskogo Universiteta, 17 (3): 52-58.

Trofimov, S.S., Titlyanova, A.A., Klevenskaya, I.A., 1979. Sistemnyy podkhod k izucheniyu protsessov pochvoobrazovaniya $\mathrm{v}$ tekhnogennykh landshaftakh [A systematic approach to the study of soil formation processes in technogenic landscapes]. In Trofimov, S.S. (ed.). Pochvoobrazovaniye $v$ tekhnogennykh landshaftakh. Novosibirsk: Nauka, p. 3-19.

Tsibart, A. S., Gennadiev, A.N., 2009. The trend of changes in forest soils of the Amur region under the influence of the pyrogenic factor. Vestnik Moskovskogo Universiteta. Seriya 5. Geografiya, 3: 66-74.

Wanner, M., Dunger, W., 2002. Primary immigration and succession of soil organisms on reclaimed opencast coal mining areas in eastern Germany. European Journal of Soil Biology, 38 (2): 137-143. https://doi.org/10.1016/ S1164-5563(02)01135-4

ZAKHAROv, S.A., 1945. Evolyutsiya pochvoobrazovaniya v svyazi s istoriyeǐ zemnoĭ kory [Evolution of soil formation in connection with the history of the Earth's crust]. Pochvovedeniye, 1: 54.

Zavarzina, A. G., ZaVArZIN, A.A., 2013. Gumus v rannikh nazemnykh ekosistemakh [Humus in early terrestrial ecosystems]. Priroda, 9: 49-58.

Working Group WRB, 2015. World Reference Base for Soil Resources 2014, update 2015. International soil classification system for naming soils and creating legends for soil maps. World Soil Resources Reports, No. 106. Rome: FAO. $192 \mathrm{p}$

Received April 20, 2021

Accepted October 26, 2021 